\title{
Application of the role-play technique for the promotion of cooperative learning in academic programs
}

\author{
Raul J. Martelo ${ }^{\# 1}$, Piedad M. Martelo Gomez ${ }^{* 2}$ Piedad M. Montero Castillo ${ }^{\$ 3}$ \\ ${ }^{\#}$ Faculty of Engineering, Research Group in Communications and Informatics Technologies GIMATICA. \\ University of Cartagena; ${ }^{1}$ rmartelog1@unicartagena.edu.co. \\ ${ }^{*}$ Faculty of Dentistry. University of La Guajira; ${ }^{2}$ pmartelog@gmail.com. \\ ${ }^{s}$ Faculty of Engineering, Food Engineering program, Research Group NUSCA. University of Cartagena; \\ 3pmonteroc@unicartagena.edu.co.
}

\begin{abstract}
The aim of this research was to promote the development of cooperative learning in university academic programs through the application of the role-play techniques, which contribute to the formation of cooperative behaviours. A model that specifies the actions done, based on in a preexperimental design was implemented that disposed of a pre-test and post-test to evaluate the impact of the technique. Based on a case study focused on the Systems Engineering program at the University of La Guajira - Colombia, it was obtained as the result the appropriation of significant learning related to software development methodologies in 20 students of the Software Engineering II course. The application of the technique allowed the knowledge appropriation of each role assigned within of a software development project through SCRUM methodology.
\end{abstract}

Keyword - Cooperative learning, meaningful learning, role-play, software development methodologies, academic program.

\section{INTRODUCTION}

Higher education is considered a mean to promote the development and consolidation of the countries. There are many ways in which Higher Educational Institutions (HEI) can contribute to particular environments within their contexts [1]. Thus, awareness of the changes that are triggered by aspects such as technology, science and innovation developments, becomes of high importance for these organizations. The above with the purpose of encouraging students to develop abilities which allow them to confront all kinds of situations [2].

The teaching approach represents one of the fundamental aspects of fulfilling such objective, as it makes it possible for the students to learn by involving their previous knowledge and motivations as a function of their own personal and professional projects [3]. This approach appeals to the interest and enthusiasm of the students, which depends on factors including content, presentation and instructor-student relation. These, in turn, are influenced by time, the number of students and the instructor's abilities [4]. However, teaching methods and techniques are often based on traditional education systems where students receive knowledge as al unalterable, unquestionable truth [5]. This situation leads to the standardization of knowledge transmission and reception in a limited way which does not cover personal meanings and transform potential components into secondary ones [6].

The above, along with new scenarios that are constantly faced by Higher Educational Institutions, has led to the search of new teaching and learning perspectives where the student could construct his own knowledge. This phenomenon contributed to the emergence of new approaches associated with relations, attitudes and solidary values such as cooperative learning, which seeks to impulse adaptation to the work and social environment of the student by emphasizing group work [7]. Some of the purposes of this approach are: to encourage the active participation of the student in the learning process; to increase learning via student-student interaction, to promote independent learning, to develop leadership skills, and to prepare the student as a citizen of the current work environment [8].

In a similar way, the impact of existing challenges that are faced by the educational field has been analysed by using tools that study in the future. One of these tools is the prospective, which consists of both pre-active and pro-active actions that aim to identify specific situations and then react accordingly to achieve desired changes through the adaptation of the actors involved [9]. In order to perform the analysis, prospective study uses a set of methods and techniques that allow the evaluators to evidence and understand relations and behaviours within the studied system. Role playing is one of these techniques in which participants play the role of another individual, acting and behaving in a way that is different to his own personality. This method aims to influence the forging of moral feelings, the development of cooperative behaviours and the preparation of individual for the work environment [10]. 
Role playing games have been used as a support tool for studies regarding: sustainable development [11], intelligent agricultural systems [12], climate change and management of water [13, 14], to name a few. The technique has also been applied in the educational field regarding studies of symbolic training [15], improvement of the oral expression [16], argumentative competences [17], assessment of college learning and development of the creative and emotional potential of college students $[18,19]$.

On the basis of the foregoing, it is worth asking the question: how can role-playing games be used to promote cooperative learning in college environments? In order to find an answer, the application of role-playing technique in a course of an academic program was established as objective of this study, the results should encourage instructors to combine or replace the traditional teaching process with modern strategies that are focused on the students by promoting significant learning [18].

With the purpose of accomplishing the objective above, the course of Software engineering II was selected as a case study within the academic program of Systems Engineering at the University of La Guajira, Colombia. This course was selected since for software projects, and especially those that are categorized as complex, require individuals to interact under a collaborative environment which allows them to control aspects such as dimension of the project, delivery times and human limitations that affect the life cycle of the software [20].

\section{Materials AND Methods}

The research was carried out using the pre-experimental pre-test, post-test approach, by evaluating the knowledge of students regarding methodologies for software development, before and after applying the roleplaying game. This means that the study involved a group of individuals from which notes were taken prior and after intervention with the purpose of analysing the observed changes [21].

The course of Software Engineering II of the Systems Engineering program of the University of La Guajira, consists of 4 credits and it is taught in the seventh semester of the curriculum. This course is taught in a theoretical-practical way, and it was selected as target to apply the technique with the purpose of highlighting the acquisition of significant learning by the students. And specifically, knowledge regarding methodologies of software development, which is the fundamental subject within the professional profile of a systems engineer. Such learning is to be achieved under a collaborative environment that is supported by role-playing games.

\section{A. Data recollection techniques}

Data collection techniques included surveys and observation that were applied to instructors of the University of La Guajira and to staff of software development companies. The purpose of this data was to determine the content of the surveys (pre-test and post-test) that the students completed before and after the application of the role-playing game. This comparison would indicate the level of learning that was achieved through the application of the technique. On the other hand, the observation allowed the assessment of the appropriation of such knowledge by recording the behaviours and conducts that were expressed by the students when applying the technique. The process was carried out at the end of the first semester of 2016. In that time, 20 students were taught concepts and theories related to software development methodologies over the course of the subject.

The surveys were applied by using a questionnaire as collection instrument, and a sample of 5 instructors and 5 entrepreneurs. The questionnaires were previously validated by instructors, whom expressed their opinions about the content through expert judgment with the purpose of ensuring the incorporation of key aspects and the removal of those considered irrelevant [22]. In the same way, reliability analysis of the questionnaires was performed by using the Cronbach alpha coefficient through the SPSS software, which quantifies the existing correlation between the parts of an instrument [23].

\section{B. Data analysis}

The results were analysed through the descriptive statistics of a scale which allowed the assessment of the knowledge that was acquired by the students during pre-test and post-test. The Wilcoxon signed-rank test was also used to verify the extent of the significant results as a function of the assessment ranks that were used [24]. This test was carried out via SPSS statistic software.

\section{Proposed conceptual model}

The research was based on the model that can be seen in Figure 1, which consists of stages: A) Data collection; B) Design and evaluation of the questionnaires; C) Development of the pre-test; D) Application of the role-playing game; E) Development of the post-test; and F) Analysis of the results. 


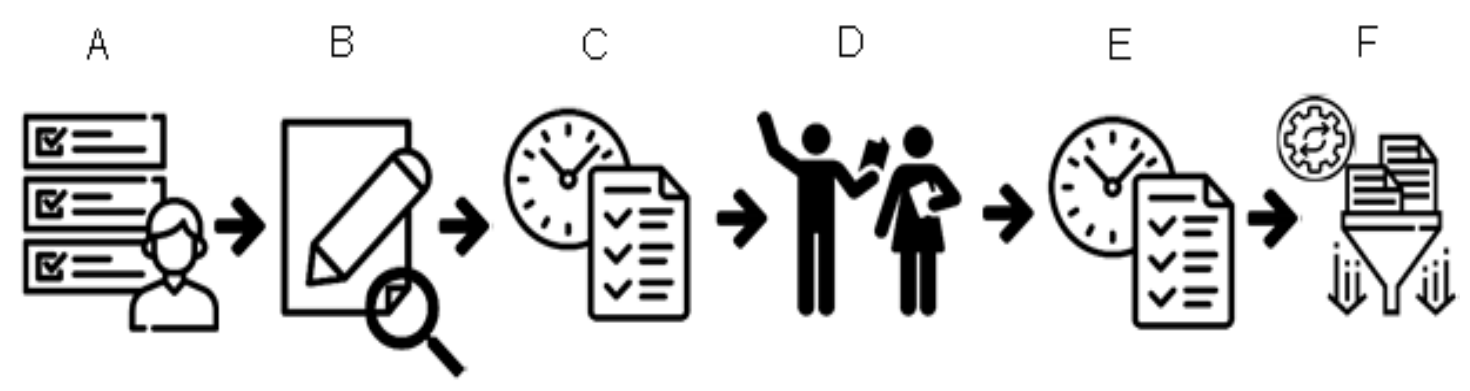

Figure 1. Proposed conceptual model

This model is described as follows:

A) Data collection: surveys were conducted on instructors and entrepreneurs that were familiar with the subject related to the case study. The data collected was to be used as a basis for the formulation of questionnaires (pre-test and post-test) that would later be applied to the students.

B) Design and evaluation of the questionnaires: once the data were collected, the questionnaires designed and subsequently evaluated by the instructors through the expert judgement technique, with the purpose of ensuring the gathering of truly relevant data related to the knowledge of the students.

C) Development of pre-tests: the first questionnaire was applied after being evaluated. It would indicate the level of knowledge that the students had regarding development methodologies that were studied throughout the semester, prior to the role-playing game.

D) Application of the role-playing game: the group was divided in several sub-groups whose members are informed about the objective and the details of the game to be played (roles, number of players per group, rules, facilitator, etc.). Each individual subsequently starts playing the role that was assigned to him/her. All participants should do so in the best possible way.

In order to develop the role-playing game, 4 groups of 5 students were created. The purpose of the activity was for the individuals to use concepts and aspects that are associated with the application of software development methodologies. Such knowledge is acquired over the course of the asignature, and they were to be applied in a practical way through collaborative learning under the focus of the SCRUM methodology, which is the most commonly used in organizations.

The above was achieved by assigning each group with a project that required the application of the SCRUM methodology for a proper development through 10-minute role-playing. In this way students could examine activities, roles and factors that relate to the methodology in a participative, active way which would contribute to the improvement of data acquisition through traditional learning. Therefore, it is necessary for college students to become involved with learning-teaching methodologies and innovative group-evaluation techniques that allow the development of new skills [18].

E) Development of the post-test: once the role-playing game is applied, students were once again evaluated with the purpose of confirming if the results of the technique led to the acquisition of significant knowledge, when compared to the pre-test results.

F) Results analysis: the final stage involved the arrangement of data according to proposed assessment scale. The data were arranged by using the Wilcoxon signed-rank test with the purpose of identifying the extent of the significant results.

\section{III.RESULTS AND DISCUSSIONS}

\section{A. Surveys}

The instructors informed about the need to incorporate questions that were related to key aspects, such as life cycle of the software, development methodologies and factors to be considered when selecting them. On the other hand, the entrepreneurs suggested the use of SCRUM or its variations, as the methodology that is most commonly used by software development companies. They also informed about inconveniences during the analysis of requirements and the appropriate application of the methodology by the staff. These two phenomena lead to non-compliances in delivery times and cost overruns. Due to the aforementioned facts, life cycle of the software was established as a topic for the role-playing game, according to the methodology that was described by the consulted entrepreneurs. 


\section{B. Results of the pre-test}

Once the questionnaires had been validated, the pre-test was applied to 20 students of the course. Table 1 shows the results that were obtained. They are arranged on the basis of an assessment scale that was designed from the rank that is used by the University of La Guajira, with 3.0 being the minimum grade to pass and 5.0 the highest grade. Thus, each question has a value of 0.5 .

Table 1. Pre-test results

\begin{tabular}{|c|c|c|}
\hline Rank & Frequency & Percentage \\
\hline $4.0-5.0$ & 2 & $10 \%$ \\
\hline $3.0-3.9$ & 7 & $35 \%$ \\
\hline $2.0-2.9$ & 9 & $45 \%$ \\
\hline $0.0-1.9$ & 2 & $10 \%$ \\
\hline Total & 20 & $100 \%$ \\
\hline
\end{tabular}

When based on the minimum grade, it can be observed that 9 students (45\%) passed the pre-test, 7 of which with grades between 3.0 and 3.9, and 2 between 4.0 and 5.0. Most of the students (55\%) obtained grades below 3.0.

\section{Application of the role-playing game}

Some of the roles that are interpreted in the game include individuals that influence directly in the development of the project, as well as some other that act as feedback to the SCRUM process (Table 2). Each group was provided with information related to the characteristics and functions of the roles to be played in the game, with the purpose of achieving an appropriate interpretation.

Table 2. Roles of the SCRUM methodology

\begin{tabular}{|c|c|}
\hline Role & Function \\
\hline Product owner & Determines the priorities of the Project \\
\hline Scrum Master & Manages and faccilitates the execution of the SCRUM rules \\
\hline Development team & Builds the Project \\
\hline Interested & Advises, observes and gives feedback to the development process \\
\hline
\end{tabular}

Special emphasis was associated with the observation of the key aspects for the development of the systems engineer during the game. Some of these aspects included: techniques of data collection, analysis of requirements, allocation of responsibilities, design, implementation, quality control and deployment of the software.

\section{Development of post test}

The role-playing game was followed by a second evaluation that would identify whether the technique contributed to the acquisition of significant knowledge or not, when compared to the pre-test. The results of this stage are shown in Table 3.

Table 3. Post-test results

\begin{tabular}{|c|c|c|}
\hline Rank & Frequency & Percentage \\
\hline $4-5$ & 5 & $25 \%$ \\
\hline $3.0-3.9$ & 11 & $55 \%$ \\
\hline $2.0-2.9$ & 4 & $20 \%$ \\
\hline $0.0-1.9$ & 0 & $0 \%$ \\
\hline Total & 20 & $100 \%$ \\
\hline
\end{tabular}

It can be observed that $80 \%$ of the students passed the second test; $25 \%$ of them with grades between $4.0-5.0$, and $55 \%$ with $3.0-3.9$. In a similar way, the percentage of students that failed the test was reduced from $55 \%$ to $20 \%$.

\section{E. Result analysis}

Once the pre-test and post-test was developed, the data was analyzed by using the Wilcoxon signed-rank test (Tables 4 and 5). 
Table 4. Wilcolxon ranks

\begin{tabular}{|l|l|l|l|l|}
\hline \multicolumn{2}{|c|}{} & $\mathbf{N}$ & Average rank & Rank sum \\
\hline Postest-pretest & Negative ranks & $3^{a}$ & 7.1667 & 21.50 \\
\cline { 2 - 5 } & & & & \\
\cline { 2 - 5 } & Possitive ranks & $16^{\boldsymbol{D}}$ & 17.718 & 187.0 \\
\cline { 2 - 5 } & Draws & $1^{\sigma}$ & & \\
\cline { 2 - 5 } & Total & 20 & & \\
\hline
\end{tabular}
a. postest $<$ pretest
b. postest $>$ pretest
c. postest $=$ pretest

Table 5. Contrast statistics ${ }^{\mathrm{a}}$

\begin{tabular}{|l|l|}
\hline & Postest-pretest \\
\hline $\mathrm{Z}$ & $-3.114^{\text {z }}$ \\
\hline Asymptotic Sig. (bilateral) & 0.002 \\
\hline
\end{tabular}

Note: a. Wilcoxon signed-tank test; $b$. Based on the negative signs

A value of $\mathrm{P}<0.05$ was obtained from the results, which indicates that there are significant differences between the grades achieved by students during pre-test and post-test and also this demonstrated the application of role-play technique is relevant to the promotion of cooperative learning, being the grades of the second evaluation higher. A similar case was found where is implemented the robotics in Lego to support the robotic cooperative learning, which it produced a $\mathrm{P}<0.01$ for the correlation of the pre-test and post-test, developing improvement in critical thinking of students, compared to practice exercises [25]. Above demonstrates, although the cooperative learning through robotics is effective, learning does not cover completely, because only improved the critical thinking, without taking into account the other competencies.

It is observed that the application of role-play technique in the teaching process facilitates the development of collaborative learning environments that promote analytical and critical abilities. In other researches, this process could be counterproductive for students with disabilities in characterizing a role due to its ideology or beliefs, which can be a little bit beneficial in the result analysis [26]. For that, conditions must be created for the student to freely express himself in an area of understanding, acceptance and respect, in order to attribute significance to the knowledge imparted to him [27]. Hence, HEI need to implement learning strategies and methodologies that contribute to the integration of the student with the constantly changing environment. In this context, role-playing games allow the individuals to feel a higher level of implication and turn data into knowledge throughout the traditional learning process [28].

\section{IV.CONCLUSIONS}

Instructors are provided with an innovative learning methodology which allows students to adapt to teamwork. There was a clear need to implement learning methodologies which covers further beyond the appropriation of concepts and theories, therefore allowing the student to put his knowledge into practice in an active and participative way.

College learning processes should contribute to the integration of the student, with the purpose of articulating the acquired knowledge to different day-to-day situations within the social and work environments. On the other hand, the methodology that was implemented can be applied through the application of other techniques that aim to identify key variables that should be considered when developing cooperative environments.

\section{REFERENCES}

[1] J. Enríquez, "Educación superior : tendencias y desafíos .," Educ. Médica, vol. 8, no. 4, pp. 10-14, 2005.

[2] L. C. Colina, "La Investigación En La Educación Superior Y Su Aplicabilidad Social," Rev. Educ., pp. 330-353, 2007.

[3] T. Moreno, "Didáctica de la Educación Superior : nuevos desafíos en el siglo XXI .," Perspect. Educ., vol. 50, pp. $26-54,2011$.

[4] A. Kucharčíková, M. Ďurišová, and E. Tokarčíková, "The Role Plays Implementation in Teaching Macroeconomics," Procedia - Soc. Behav. Sci., vol. 174, pp. 2489-2496, 2015.

[5] M. I. Torres, "La enseñanza tradicional de las ciencias versus las nuevas tendencias educativas," 2010.

[6] F. Bovi, A. Palomino, and J. J. González, "Evaluación y contraste de los métodos de enseñanza tradicional y lúdico," Apunt. Educ. física y Deport., vol. 2008, no. 94, pp. 29-36, 2008.

[7] P. Aramendi Jauregui, K. Bujan Vidales, S. Garín Casares, and A. Vega Fuente, "Estudio de Caso y Aprendizaje Cooperativo en la Universidad," vol. 18, pp. 413-429, 2014.

[8] M. R. García-Ruiz and N. González-Fernández, El aprendizaje cooperativo en la universidad . valoración de los estudiantes respecto a su potencialidad para desarrollar competencias, vol. 3, no. 5. 2013.

[9] M. Godet and P. Durance, Prospectiva Estratégica: problemas y métodos, 2nd ed. 2007.

[10] L. Mengana-lorenzo and Z. de la C. Matos-Columbié, "La orientación profesional en la infancia preescolar . Actualidad y perspectiva desde el juego de roles," vol. 16, no. 56, pp. 98-106, 2016. 
[11] F. Gourmelon, F. Chlous-Ducharme, C. Kerbiriou, M. Rouan, and F. Bioret, "Role-playing game developed from a modelling process: A relevant participatory tool for sustainable development? A co-construction experiment in an insular biosphere reserve," Land use policy, vol. 32, pp. 96-107, 2013.

[12] G. Salvini, A. van Paassen, A. Ligtenberg, G. C. Carrero, and A. K. Bregt, "A role-playing game as a tool to facilitate social learning and collective action towards Climate Smart Agriculture: Lessons learned from Apuí, Brazil," Environ. Sci. Policy, vol. 63, pp. 113$121,2016$.

[13] J. Sterman et al., "World Climate: A Role-Play Simulation of Global Climate Negotiations," Simul. Gaming, vol. 46, no. 3-4, pp. 348$382,2015$.

[14] T. Hertzog, J. C. Poussin, B. Tangara, I. Kouriba, and J. Y. Jamin, "A role playing game to address future water management issues in a large irrigated system: Experience from Mali,” Agric. Water Manag., vol. 137, pp. 1-14, 2014.

[15] C. X. González-Moreno, "Formación de la función simbólica por medio del juego temático de roles sociales en niños preescolares," Rev. la Fac. Med., vol. 63, no. 2, pp. 235-241, 2015.

[16] R. :Gutierrez R. Lopez, "Juegos de rol basados en el aprendizaje significativo para mejorar la expresión oral en los estudiantes," Crescendo Educ. y Humanidades, vol. 3, no. 1, pp. 43-52, 2016.

[17] A. García-Barrera, "Importancia de la competencia argumentativa en el ámbito educativo: una propuesta para su enseñanza a través del role playing online," 2015.

[18] R. A. Gaete-Quezada, "El juego de roles como estrategia de evaluación de aprendizajes universitarios," Educ. y Educ., vol. 14, no. 2, pp. 289-307, 2011

[19] S. B. Dyson, Y. L. Chang, H. C. Chen, H. Y. Hsiung, C. C. Tseng, and J. H. Chang, "The effect of tabletop role-playing games on the creative potential and emotional creativity of Taiwanese college students,” Think. Ski. Creat., vol. 19, pp. 88-96, 2016.

[20] J. C. Caiza, D. S. Guamán, and G. R. López, "Herramientas de desarrollo con soporte colaborativo en Ingeniería de Software," Enfoque UTE, vol. 6, no. 2, pp. 102-116, 2015.

[21] C. Manterola and T. Otzen, "Estudios Experimentales 2a Parte . Estudios Cuasi-Experimentales," vol. 33, no. 1, pp. 382-387, 2015.

[22] P. Robles and M. del Carmen, "La validación por juicio de expertos: dos investigaciones cualitativas en Lingüística aplicada.," Rev. Nebrija Lingüística Apl. a la Enseñanza Lenguas, no. 18, p. 103, 2015.

[23] J. González and M. Pazmiño, "Cálculo e interpretación del Alfa de Cronbach para el caso de validación de la," Rev. Publicando, vol. 2, no. 1 , pp. $62-77,2015$.

[24] G. Divine, H. J. Norton, R. Hunt, and J. Dienemann, "A Review of Analysis and Sample Size Calculation Considerations for Wilcoxon Tests," Anesth. Analg., vol. 117, no. 3, pp. 699-710, Sep. 2013.

[25] P. Mosley, G. Ardito, and L. Scollins, "Robotic Cooperative Learning Promotes Student STEM Interest,” Am. J. Eng. Educ., vol. 7, no. 2, pp. 117-128, 2016.

[26] R. Stevens, "Role-play and student engagement: reflections from the classroom," Teach. High. Educ., vol. 20, no. 5, pp. 481-492, 2015.

[27] J. Rodriguez, “Una mirada a la pedagogía tradicional y humanista," Presencia univeristaria, vol. 3, no. 5, pp. 36-45, 2013.

[28] Ma. Grande and V. García, "Los juegos de rol en el aula," Teoría la Educ. Educ. y Cult. en la Soc. la Inf., vol. 11, no. 3, pp. 56-84, 2010.

\section{AUTHOR PROFILE}

Raul J. Martelo works as full-time professor at the University of Cartagena (Colombia). Mr. Martelo completed his magister from Industrial University of Santander (Colombia). Mr. Martelo completed his undergraduate in Systems Engineering at the Industrial University of Santander.

Piedad M. Martelo Gomez works as part-time professor at the University of Cartagena (Colombia). Mrs. Martelo completed her specialization studies from Universidad of Cartagena. Mrs. Martelo completed his undergraduate in Dentistry at the University of Cartagena.

Piedad M. Montero Castillo works as full-time professor at the University of Cartagena (Colombia). Mrs. Montero completed his doctorate from Universidad Rafael Belloso Chacin (Venezuela). Mrs. Montero completed his undergraduate in Food Engineering at the University of Cartagena. 